\title{
Stress Management Training for Children in Conflict with the Law in Antara House in Social Home X
}

\author{
Pristin Salmiati $^{\mathrm{a}}$, Nilam Widyarini ${ }^{\mathrm{b}}$ \\ ${ }^{a}$ Gunadarma University, Indonesia (pristin.salmiati@gmail.com) \\ ${ }^{b}$ Gunadarma University, Indonesia (nilam.wid@gmail.com)
}

\begin{abstract}
Children in Conflict with the Law are children who have commited criminal acts, while Antara House in Social Orphanage $\mathrm{X}$ is one of the social rehabilitation institutions that becomes a reference for Children in Conflict with the Law care during the legal process. Generally, Children in Conflict with the Law experiences stress due to their displacement of life to Antara House in Social Orphanage $X$ which is bound by a number of rules and the uncertainty of their conditions after moving out from Antara House in Social Orphanage X. The aim of this study was to reduce the stress level of Children in Conflict with the Law in Antara House in Social Orphanage X by using stress management training. The subjects in this study were 19 Children in Conflict with the Law in Antara House in Social Orphanage X. Training is carried out by providing pre-tests, conducting training, providing post-tests and evaluating training. The pre-test and posttest in this study used a stress level scale. The results of this study were that there was a reduction in stress levels at 19 Children in Conflict with the Law in Antara House in Social Orphanage X. The analysis results from the Wilcoxon test showed that stress management training could significantly reduce stress on Children in Conflict with the Law in Antara House in Social Orphanage $X(Z=-3,835 ; \mathrm{p}<0.00)$. The training conducted for Children in Conflict with the Law in Antara House in Social Orphanage X tends to be effective for several reasons, such as giving them the opportunity to be involved in discussions, filling in worksheets, practicing deep breathing techniques, openness to tell stories after the training, correlateness of the training with the problems they face and training with other topics that are relevant and implemented on an ongoing basis.
\end{abstract}

(C) 2021 Published by IJRP.ORG. Selection and/or peer-review under responsibility of International Journal of Research Publications (IJRP.ORG)

Keywords: Stress, Stress Management, Children in Conflict with the Law

\section{Preliminary}

In the last few years, there have been various problems with children in Indonesia which are quite diverse. One of the issues that is of considerable concern is children who commit crimes or are also known as Children in Conflict with the Law. During 2011-2017 there were a total of 9,266 cases involving Children in Conflict with the Law. The highest number occurred in 2014, which reached 2,208 cases. The second highest was in 2013 with 1,428 cases. Meanwhile, the third highest number was 1,413 cases in 2012. In addition, there were children who acted as perpetrators of these cases. In 2017, there were 116 cases of children as perpetrators of sexual violence. Meanwhile, there were 134 children who were victims of sexual violence (Setyawan, 2017). KPAI (The Indonesian Child Protection Commission) also noted that the Children in Conflict with the Law case was ranked as the highest complaint until May 2018. Of the 1885 complaints 
received, 504 of them (27\% of the total cases) were Children in Conflict with the Law cases (Primastika, 2018).

\section{Research Methods}

The subjects of this study were 19 Children in Conflict with the Law who were in Antara House in Social Orphanage X. The ages of subjects are in the range of 10-18 years. Selection of subjects based on criteria, namely Children in Conflict with the Law lives in Antara House in Social Orphanage X, is undergoing a legal process and at least experiencing moderate levels of stress. Even so, there were three subjects that were known to experience low levels of stress but were still included in stress management training for reasons of uniformity of subjects activities. The research design used was a quasi-experimental one group pre test post test.

Stress management training refers to the stress management theory described by Soewondo, Menaldi, and Hanum (2017). This training consists of four sessions over a period of four consecutive days. In one day, Children in Conflict with the Law received one session of training. The duration of each session ranges from 90-120 minutes. The material was delivered through lectures and video screenings related to the training topic. Children in Conflict with the Law is given worksheets in each training session. In addition, Children in Conflict with the Law was also invited to practice deep breathing techniques to relieve the tension they feel on their bodies. Children in Conflict with the Law is given the opportunity to discuss with the speakers before the end of a session.

The measuring instrument in this study is the stress level scale compiled by Soewondo, Menaldi, and Hanum (2017). However, there are modifications that researchers have made on the post-test sheet and have received prior professional judgment. The stress level scale refers to the Perceived of Stress Scale (PSS) developed by Cohen, Kamarck and Mermelstrein (1983). PSS is a psychological instrument that measures an individual's picture of the stress they experience in their life. Each item on the PSS scale is designed to detect how much an individual finds that things in his life are unpredictable (unpredictable), uncontrollable (uncontrollable) and overloaded (overload) in the last one month. The consistency of internal reliability is indicated by Cronbach's alpha scores of $.86, .85$ and .84 in three samples at the University of Oregon (Cohen, Kamarck and Mermelstrein, 1983) and Cronbach's alpha score of .85 in the Wongpakaran and Wongpakaran (2010) study of a sample of 479 individuals in two hospitals located in Northern Thailand. There are 10 items on the PSS scale with five response options worth $0-5$. The scoring is adjusted to the selected response. However, items 4, 5, 7 and 8 were scored in reverse. The total score will be in the range $0-40$ where the higher the score obtained, the higher the level of stress being experienced by the subject. A score of 0-13 indicates a low stress level, a score of 14-26 indicates a moderate stress level and a score of 27-40 indicates a high stress level.

\section{Result and Discussion}

\subsection{Results}

The results of the Children in Conflict with the Law pre-test score who attended the training found that there were sixteen subjects under moderate stress and three subjects under low stress levels. After the implementation of the training, the results of the post-test scores showed a decrease in stress level scores for all subjects. The results of the pre-test and post-test evaluation can also be seen through the graph below: 


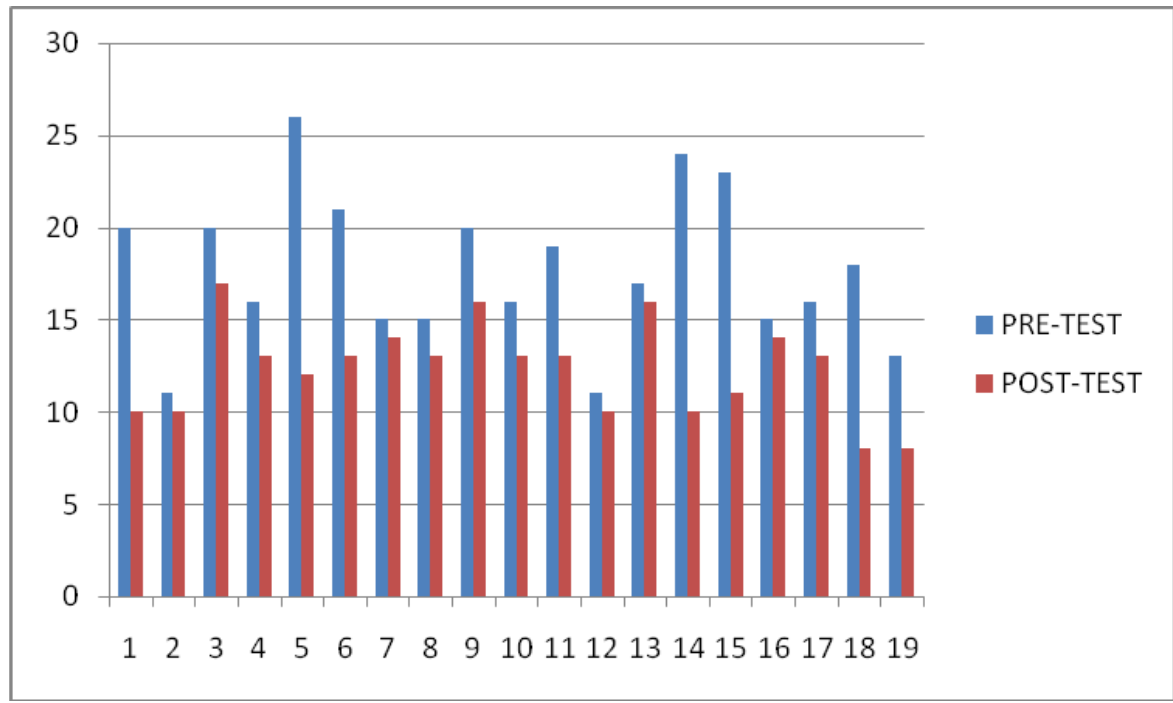

Picture 1. The result of stress level questionnaire pre-test and post-test children before the law

Based on the graph above, it can be concluded that all Children in Conflict with the Law in Antara House in Social Orphanage $\mathrm{X}$ who participated in stress management training activities experienced a decrease in stress level scores. The results of this study indicate that stress management training is quite successful in improving Children in Conflict with the Law's ability to understand, recognize and manage stress in daily life for one week after the training.

The nonparametric statistical test used in this study is the Wilcoxon test for two related samples. The aim is to test for differences in stress levels before and after training. Data analysis was performed using SPSS 15.0 for Windows. The data regarding the Wilcoxon test results are shown in the following table:

Table 1. Average Pre- Test and Post- Test Results

\begin{tabular}{llllll}
\hline & $\mathrm{N}$ & Mean & Std. Deviation & Minimum & Maximum \\
\hline Pretest & 19 & 17.6842 & 4.13726 & 11.00 & 26.00 \\
Posttest & 19 & 12.3158 & 2.56152 & 8.00 & 17.00 \\
\hline
\end{tabular}

Table 2. Statistics based on The Wilcoxon Signed Ranked Test

\begin{tabular}{ll}
\hline & Posttest-Pretest \\
\hline$Z$ & -3.835 (a) \\
Asymp. Sig. (2-tailed) & .000 \\
a. Wilcoxon Signed Rank Test & \\
b. Based on positive ranks & \\
\hline
\end{tabular}

From the results of the Wilcoxon test can be concluded that there is a decreased stress level scores in the subject before and after being given the intervention, this can be seen from the $Z$ value is $-3,835$ with a significance value $(p)=0,000(p<0.01)$ so that it can be concluded the results are very significant. 


\subsection{Discussion}

The results of the assessment show that one of the problems faced by Children in Conflict with the Law in Antara House in Social Home X is stress. They tend to experience tension, confusion and pressure that make them less comfortable in living their daily lives. This condition is also supported by the lack of knowledge of them about stress and stress management so that it can encourage them to do things that are destructive or detrimental without solving their real problems. Some of the causes that Children in Conflict with the Law in Antara House in Social Home X say are the displacement of their lives from the home environment with their families which is a comfort zone to Antara House in Social Home X, restrictions on freedom, negative views from other people, the absence of persons who can be invited to tell stories about their problems and also the decrease in motivation to achieve their goals after leaving Antara House in Social Home X.

The explanation above is in line with the opinion of Soewondo, Menaldi, and Hanum (2017) which states that life events are examples of external stressors in individuals. A similar opinion was conveyed by Shahsavarani, Abadi, and Kalkhoran (2015) who said that stressors originating from outside the individual can occur through changes in the environment the individual lives in. Life events that Children in Conflict with the Law face is the movement of life into Antara House in Social Home X which limits their freedom in activities and meeting with family and friends. In addition, they are also required to live in a new environment together with new people who are also newly known for a long and intensive period of time every day. However, in the midst of the inconvenience, they have not found persons who are considered capable of sharing stories about their problems so that their lives in Antara House in Social Home X tend to be tense.

After the implementation of stress management training, it is known that there is a significant decrease in stress level scores in Children in Conflict with the Law in Antara House in Social Home X before and after the training. This is indicated by the $Z$ value of -3.835 with a significance value of $0.000(p<0.01)$ and a decrease in the mean post-test score. Based on quantitative results, it is known that all subjects who participated in stress management training activities experienced a decrease in stress level scores. The results of this study are in line with the research of Burkhark, Mason, and Lazebnik (2017) which showed a decrease in stress levels in thirty adolescent patients at a clinic in the Cleveland area, United States after stress management training. In addition, the research of ztürk and Ocakçı (2016) also found that stress management training was able to bring about positive behavioral changes in 37 prisoners in juvenile prisons in Turkey in managing stress.

The success of stress management training is possible because of the opportunity for Children in Conflict with the Law in Antara House in Social Home X to be directly involved in discussion activities, filling out worksheets and practicing deep breathing techniques. The training activities are also interspersed with an ice breaking program, showing videos and parable stories related to the material in order to establish a relatively relaxed, fun and supportive condition during the delivery of the material. After the stress management training took place, it was seen that there were efforts by Children in Conflict with the Law in Antara House in Social Home X to share the problems they faced by visiting researchers. This allows Children in Conflict with the Law in Antara House in Social Home X to practice seeing the problems they face from a different perspective. Some Children in Conflict with the Law in Antara House in Social Home X also said that they felt more relaxed when practicing deep breathing. Their tension is also better able to be minimized when resting at night and there is a sense of relief because they can share stories. According to Silberman (in Thoomazen \& Murtini, 2014) these activities are learning through experience. Learning through experience is the most effective method to increase understanding in the training process because the learning process that occurs involves individuals to pay attention, analyze, seek understanding and then apply that knowledge and understanding in behavior. In addition, the factors that support the success of stress management training are also inseparable from the support of other continuous psychological interventions, 
namely in the form of training. The topics presented in other trainings are about self-concept, emotional intelligence and goal setting.

Furthermore, the condition of the Children in Conflict with the Law in Antara House in Social Home $\mathrm{X}$ during the assessment and training tended to refer to emotion focus coping in dealing with stressors. Examples of emotion focused coping are crying, praying, joking with friends and sleeping. This is related to the economic and educational background of the Children in Conflict with the Law in Antara House in Social Home $\mathrm{X}$ who are at the lower to middle level and the limitations of making changes to stressful situations. The increased support from fellow friends at Antara House in Social Home X and a number of practical students were felt to be quite helpful for them in sharing stories about the problems they faced. In addition, the various positive activities provided by the social workers in Antara House in Social Home X also played a role in easing the tensions and pressures that Children in Conflict with the Law in Antara House in Social Home X felt. Some examples of positive activities in Antara House in Social Home X environment are social guidance class, sports and marches class. The Children in Conflict with the Law in Antara House in Social Home $\mathrm{X}$ were also given the opportunity to do some of their fun activities during the training, such as drawing, writing and storytelling. The openness of the Children in Conflict with the Law in Antara House in Social Home $\mathrm{X}$ in receiving knowledge from several intervention themes was also quite helpful for them to see their problems from another point of view.

The above conditions are in line with research by Compass (2001) which states that emotion-focused coping tends to be used more by children and adolescents in dealing with stress. Lazarus and Folkman (in Compas, 2001) explain that emotion-focused coping involves responses such as expressing feelings and thoughts experienced, seeking social support from others and trying to avoid sources of stressors. Soewondo, Menaldi, and Hanum (2017) explain that people with lower to middle economic and educational backgrounds tend to use emotion-focused coping more. This is due to the limited resources they have to change the pressing situation they face, even if the situation is often irreversible. Emotion-focused coping is a stress management strategy aimed at controlling emotional responses due to stressful situations. Some ways that can be done to manage emotions when stressed are seeking social support from family or closest relatives, engaging in activities in the surrounding environment, doing fun activities.

\section{Conclusions and Recommendations}

\subsection{Conclusions}

Children in Conflict with the Law in Antara House in Social Home X has a problem in the form of stress. They experience tension, confusion and pressure that make them less comfortable in living their daily lives. This condition is also supported by the lack of their knowledge about stress and stress management so that it can encourage them to do things that are destructive or detrimental without solving their real problems.

The results showed that stress management training was able to significantly reduce stress level scores in Children in Conflict with the Law in Antara House in Social Home X. The conclusion refers to the $Z$ value of -3.835 with a significance value of $0.000(p<0.01)$ and a decrease in the mean post-test score obtained from the Wilcoxon test. The effectiveness of stress management training is possible because of the opportunity for Children in Conflict with the Law in Antara House in Social Home X to be directly involved in discussion activities, filling out worksheets and practicing deep breathing techniques. The training activities are also interspersed with an ice breaking program, showing videos and parable stories related to the material in order to create a relatively relaxed, fun and supportive condition during the delivery of the material. After the stress management training took place, it was seen that there were efforts by Children in Conflict with the Law in Antara House in Social Home X to share the problems they 
faced by visiting researchers. In addition, stress management training is carried out continuously with other training themed on self-concept, emotional intelligence and goal setting. This allows Children in Conflict with the Law in Antara House in Social Home X to practice seeing the problems they face from a different perspective.

\subsection{Recommendations}

Future researchers are expected to be able to include all Children in Conflict with the Law in Antara House in Social Home X in training so that the results obtained will be more comprehensive with a larger number of participants. Future researchers can also provide stress management training to social workers to maintain harmony in assisting Children in Conflict with the Law in Antara House in Social Home X.

It is recommended for Children in Conflict with the Law in Antara House in Social Home X to try to do positive activities that they enjoy to expand their creativity and develop their potential. It also serves to relieve tension when problems arise. In addition, they are expected to learn to share stories with other friends, visiting families, social workers and psychologists on duty so that stressful situations can be handled properly. Children in Conflict with the Law in Antara House in Social Home X should still try to practice "deep breathing" when feeling tense or having trouble sleeping.

\section{References}

Burkhart, K., Mason, E., \& Lazebnik, R. (2017). Stress management intervention: A pilot evaluation in an urban adolescent medicine clinic. Clinical Pediatrics Journal, 57 (6), 700-705. Doi: 10.1177/0009922817733704

Cohen, S., Kamarck, T., \& Mermelstein, R. (1983). A global measure of perceived stress. Journal of Health and Social Behavior, 24, 385-396. Doi:10.2307/2136404

Compas, B. E., Connor-Smith, J.K., Saltzman, H., Thomsen, A.H., \& Wadsworth, M. E. (2001). Coping with stress during childhood and adolescence: Problems, progress, and potential in theory and research. Psychological Bulletin, 127 (1), 87-127.

Harvey, J., \& Smedley, K. (2010). Psychological Therapy in Prison and Other Secure Settings. New York:Willan Publishing. Diakses dari: http://opac.lib.idu.ac.id/unhan-ebook/assets/uploads/files/e5e7a-144.psychological-therapy-in-prisons-and-other-settings.pdf

Kholidah, E.N., \& Alsa, A. (2012). Berpikir positif untuk menurunkan stres psikologis. Jurnal Psikologi, 39 (1), 67-75. Doi: 10.22146/jpsi.6967

Öztürk, Ö., \& Ocakçı, A.F. (2016). The effect of stress management training program on stress coping styles among the adolescents in prison in turkey. Stress and Health, 33(3), 278-287. Doi: 10.1002/smi.2707

Primastika, W. (2018). Penyebab Kriminalitas Anak: Kurang kasih sayang \& pengakuan sosial. Diakses pada25 Agustus 2018 , dari https://tirto.id/penyebab-kriminalitas-anak-kurang-kasih-sayang-pengakuan-sosial-cP3F,)

Shahsavarani, A.M., Abadi, E.A.M., \& Kalkhoran, M. A. (2015). Stress: Facts and theories through literature review. International Journal of Medical Reviews, 2 (2), 230-241.

Setyawan D. (2017). KPAI : Kurun Waktu 6 Tahun, ABH Sudah Mencapai 9.266 Kasus. Diakses pada 25 Agustus 2018 , dari http://www.kpai.go.id/berita/kpai-kurun-waktu-6-tahun-abh-sudah-mencapai-9-266-kasus,).

Soewondo, S., Menaldi, A., \& Hanum, L. (2017). Stres, Manajemen Stres dan Relaksasi Progresif. Depok: LPSP3 UI.

Thoomaszen, F. W., \& Murtini. (2014). Manajemen stres untuk menurunkan kecemasan menghadapi ujian nasional siswa sekolah menengah pertama. Humanitas, 11 (2), 79-92. Doi : 10.26555/humanitas.v11i2.2331

Turney, K., Lee, H., \& Comfort, M. (2013) Discrimination and psychological distress among recently released male prisoners. American Journal of Men's Health, 7 , 482-493. Doi: 10.1177/1557988313484056

Wongpakaran, N., \& Wongpakaran, T. (2010). The thai version of the PSS-10: an investigation of its psychometric properties. Biopsychosos Med, 4 (6), 1-6. Doi: 10.1186/17510759-4-6 